\title{
EFFECT OF PHOSPHATE AND SOME MICRONUTRIENT FERTILIZATION ON GROWTH, YIELD AND CHEMICAL CONSTITUENTS OF SUNFLOWER(Helianthus annuus L.) PLANTS GROWN UNDER NEWLY RECLAIMED SOIL CONDITIONS
}

\author{
Sameer, S.S. El-Ganaini
}

Agricl. Botany Dept., Fac. Agric., Fayoum Univ.

\begin{abstract}
A field trial was conducted during the two successive seasons of 2007 and 2008 in the Experimental Farm at Demo (a newly reclaimed soil), Faculty of Agriculture, Fayoum University to investigate the influence of phosphate fertilizer at the rates of 0,100 , 200 and $300 \mathrm{~kg} / \mathrm{fed}$ as (calcium superphosphate, $15.5 \% \mathrm{P}_{2} \mathrm{O}_{5}$ ) before planting during soil preparation, and /or some micronutrients combined fertilizer of Pholaz D, ( $2.8 \% \mathrm{Fe}, 2.8 \% \mathrm{Zn}$ and $9.2 \% \mathrm{Mn}$ ) as foliar spray with three concentration $0,0.1$ and $0.3 \%$,alone or in combination with each other on improving growth, seed or oil yields, and some chemical constituents of sunflower plants (Helianthus annuиs L.) under a newly reclaimed soil. The obtained data showed significant positive influences of all phosphate and micronutrients treatment used in this study were observed on growth, yields of seeds or their oil contents and some chemical constituents in both tested seasons. In comparison with the control, treated plants with phosphate and micronutrients at all studied rates significantly increased vegetative growth traits (i.e., plant height, number of leaves/plant, total leaf area/plant and dry weight of leaves/plant), seed yield /fed and its components (i.e. head diameter, head dry weight, seeds weight /plant, 100 seed weight ), in addition to some nutrients( i.e., N, P, K, Fe, Mn, Zn) and chemical constituents (i.e., total carbohydrates, crude protein and seed oils). The maximum increases in the studied plant parameters were resulted from using phosphate fertilizer at the rate of $300 \mathrm{~kg} / \mathrm{fed}$ and combined fertilizer of micronutrients at the rate of $0.3 \%$ alone or together.

In view of these results, it could be concluded that treated sunflower plants with phosphate at the rate of $300 \mathrm{~kg} / \mathrm{fed}$ and the used combined fertilizer of micronutrients at the rate of $0.3 \%$ alone or together producing on economic yield for each of seed and its oil content.
\end{abstract}

Key words: Sunflower, Helianthus annuus L., phosphate, micronutrients and a newly reclaimed soils.

\section{INTRODUCTION}

Sunflower (Helianthus annuus L.) is one of the most important edible oil crops in the World. Sunflower seeds contain a high concentration of poly unsaturated fatty acids. The production of vegetable oils in Egypt is so limited and fails to meet the increasing rate of consumption of vegetable oil produced mainly from cotton seeds. However, the expansion of area devoted to cotton cultivation seemed to be hard due to limited cultivated area, intensive crop rotation and other factors. Thus, increasing production of vegetable oils must depends on the newly oil crops such as sunflower that cultivated in the newly reclaimed soils for expanding cultivated area in Egypt. The plants grown

Fayoum J. Agric. Res. \& Dev., Vol.23, No.2, July, 2009 
under this soil are sufferingfrom the shortage in phosphorus and some microelement, which were fixed by calcium carbonat.

Phosphorus is well known to be one of the most important major nutrients required by both plants and microorganisms. Moreover, it plays an important role in certain essential steps in accumulation and release of energy during cellular metabolism. So, it is of important to keep this nutrient in an available or mobile form in soil for enhancing its uptake by plant roots. On the other hand, the adverse effect in soils of Egypt, especially the alkaline condition of soils characterized by calcareous in nature, rapidly converted $\mathrm{P}$ to unavailable form due to the released $\mathrm{Ca}^{2+}$ that is precipitated $\mathrm{P}$ in a form of $\mathrm{Ca}_{3}\left(\mathrm{PO}_{4}\right)_{2}$. However in Egypt, soils suffering some deficiencies of micronutrients especially Fe, Zn, and Mn (Fawzi, 1991). Many investigators agreed that foliar spray with micronutrients (Fe, $\mathrm{Zn}$ and $\mathrm{Mn}$ ) and phosphorus as soil application increased growth characters (i.e. plant height, number of leaves/plant etc....), yield and its components(i.e. weight of 100 seed, straw yield, seed yield, etc...), chemical constituents of leaves (N, P, K, Fe, Mn, Zn) and enzyme activity as well as seed content from protein and oils (i.e., Prabhurai et al.( 1995); Ranieri et al. (1999); Ranieri et al. (2001); Seaf El Yazal, (2004) and Rahimizadeh et al. (2007) on sunflower plants; Rehan et al. (2003); Seaf El-Yazal and Sayim (2004) and Mabrouk and Zayed (2004) on faba bean; El-Yazal (2007) on maze; Elayan (2008) on cotton and Soudi et al.( 2008) on sugar beet plants.

Accordingly, the present work was planned for studying the effect of phosphorus and some micronutrients at different rates on growth, seed and oil yields, as well as some chemical constituents of sunflower plants grown under newly reclaimed soil conditions .

\section{MATERIAL AND METHODS}

A field trial was carried out during the two successive summer seasons of 2007 and 2008 in the Experimental Farm at Demo (a newly reclaimed soil), Faculty of Agriculture, Fayoum University, Egypt. This study aimed to evaluate the influence of phosphate as soil application and some micronutrient as foliar spray on growth, seed or oil yield and some chemical constituents of sunflower plants (Helianthus annuus L.) cultivated in a newly reclaimed soil. Before sowing, soil samples to a $25 \mathrm{~cm}$ depth from were collected and analyzed by using the standard procedures of Jackson (1967). The obtained results of some the experimental site soil physical and chemical properties as well as some available nutrient contents are shown in Table (1).

Seeds of sunflower (cv. Sakha 53) obtained from oil Research Ministry of Agriculture. were sown on $15^{\text {th }}$ of May in the two successive seasons (2007 and 2008). The experimental unit consisted of 7 ridges, five seeds were sown each in hill $20 \mathrm{~cm}$ apart on one side ridges ( $4.0 \mathrm{~m}$ long and $0.5 \mathrm{~m}$ width).

Fertilization:- All treatments receiving nitrogen fertilizer at the rate of 60 $\mathrm{kg} \mathrm{N} /$ fed as ammonium nitrate $(33.5 \% \mathrm{~N})$ and potassium sulphate $\left(48 \% \mathrm{~K}_{2} \mathrm{O}\right)$ at the rate of $25 \mathrm{~kg} \mathrm{~K}_{2} \mathrm{O} / \mathrm{fed}$. Nitrogen quantity was divided into 3 equal doses , the first was added at sowing, while the second and third doses were added after one and two months from planting. Potassium was added with the second dose of applied N. Recommended cultural practices for growing sunflower plants were followed. Treatments: Plants were treated with phosphate fertilizer (P) at the rates of $0,100,200$ and $300 \mathrm{~kg} / \mathrm{fed}$ as calcium superphosphate $\left(15.5 \% \mathrm{P}_{2} \mathrm{O}_{5}\right)$ before planting during soil preparation. Combined fertilizer of

Fayoum J. Agric. Res. \& Dev., Vol.23, No.2, July, 2009 
EFFECT OF PHOSPHATE AND SOME MICRONUTRIENT........ 96 micronutrients $\mathrm{M}$, (Pholaz D) which contains $2.8 \% \mathrm{Fe}, 2.8 \% \mathrm{Zn}$ and $9.2 \%$ Mn was added as foliar spray with three concentrations $0,0.1$ and $0.3 \%$. It is commercially combined fertilizer produced by Phosyn International Company, UK. Triton B as a wetting agent at $0.1 \%$ was added to the micronutrients solutions. Foliar spraying was carried out till runoff., however the amount of treatments were divided into two equal dose. The first dose was added after 4 weeks from sown, and the second dose was added after 2 weeks from the first one in addition to plants of the control treatment were sprayed only with tap water.

Table (1): Some physical and chemical properties of the experimental soil before sowing during 2007 and 2008 seasons.

\begin{tabular}{|c|c|c|}
\hline Properties & 2007 & 2008 \\
\hline \multicolumn{3}{|l|}{ Physical: } \\
\hline Clay \% & 28.00 & 28.80 \\
\hline Silt \% & 21.00 & 20.70 \\
\hline Sand \% & 51.00 & 50.50 \\
\hline Soil texture & Sandy clay loam & Sandy clay loam \\
\hline \multicolumn{3}{|l|}{ Chemical: } \\
\hline pH (1: 2.5) & 7.71 & 7.74 \\
\hline $\mathrm{EC}_{\mathrm{e}}\left(\mathrm{dSm}^{-1}\right)$ & 7.80 & 7.82 \\
\hline Organic matter $\%$ & 1.27 & 1.26 \\
\hline $\mathrm{CaCO}_{3} \%$ & 8.50 & 8.53 \\
\hline Total N \% & 0.06 & 0.07 \\
\hline \multicolumn{3}{|c|}{ Available nutrients ( $\mathrm{mg} \mathrm{kg}^{-1}$ soil): } \\
\hline K & 162.00 & 166.36 \\
\hline $\mathrm{P}$ & 6.50 & 7.22 \\
\hline $\mathrm{Fe}$ & 5.47 & 5.51 \\
\hline $\mathrm{Mn}$ & 1.88 & 1.02 \\
\hline $\mathrm{Zn}$ & 0.79 & 0.84 \\
\hline
\end{tabular}

Vegetative growth traits:

Fifty days after planting, 3 plants were randomly chosen from each experimental unit and cut off at ground level and submitted to the following determinations: plant height $(\mathrm{cm})$, No. of leaves/ plant, total leaves area /plant $\left(\mathrm{cm}^{2}\right)$ and dry weights of leaves/ plant

1. Seed yields and their components:

Ninety five days after sowing (at harvest stage), heads were picked from 3 randomly selected plants in each experimental unit and air-dried for 3 days, then seeds were manually extracted. Heads and their seeds were subjected to the following estimations: head diameter, head dry weight ,seed weight/plant , 100 seed weight $(\mathrm{g})$. Seed yield $\mathrm{fed}^{-1}(\mathrm{~kg})$ was calculated by using all heads of plants remained in all experimental units.

\section{Chemical constituents:}

Seven weeks after planting, leaves of 3 randomly selected plants were collected from each experimental plot for chemical determinations. The following parameters were determined using dry matter of leaves. Nitrogen $\%$ was colorimetrically determined by using the Orange $\mathrm{G}$ dye according to the method of Hafez and Mikkelsen (1981). As for $\mathrm{P}, \mathrm{K}, \mathrm{Fe}, \mathrm{Mn}$ and $\mathrm{Zn}$ determinations, the wet digestion of $0.1 \mathrm{~g}$ of fine dry material of leaves of each treatment was done with sulphuric and perchloric acids as mentioned by Piper

Fayoum J. Agric. Res. \& Dev., Vol.23, No.2, July, 2009 
(1947). Phosphorus \% was colorimetrically estimated using chlorostannus molybdo-phosphoric blue color method in sulphuric acid system as described by Jackson (1967). Potassium \% was determined using a Perkin-Elmer, Flame Photometer (Page et al., 1982). Iron, manganese, and zinc concentrations \% were determined using a Perkin-Elmer, Model 3300, Atomic Absorption Spectrophotometer according to Chapman and Pratt (1961).

At harvest the seeds were collected for determination some chemical constituents, i.e., seed total carbohydrates that were colorimetrically determined (mg g D. W.) by using phosphomolybdic acid reagent according to Dubois et al. (1956), and phenol-sulphoric acid reagent methods as outlined by Herbert $\boldsymbol{e t}$ al. (1971), respectively. Crude protein percentage in seeds was determined according to A.O.A.C. (1995), and seed oil yield \% was determined in the air-dried seeds according to the method described by A.O.A.C. (1995) using Soxhlet apparatus and petroleum ether $\left(60-80{ }^{\circ} \mathrm{C}\right)$ as solvent. Oil yield fed $^{-P}(\mathrm{~kg})$ was calculated by multiplying seed yield feddan ${ }^{-1}$ $(\mathrm{kg}) \times$ oil $\%$ of seeds.

\section{Statistical analysis:}

The experiment was design in a complete randomized block with 4 replicates for each treatment and total 12 treatments. The obtained results were statistically analyzed using the L.S.D at probability level of $5 \%$ for comparisons (Gomez and Gomez, 1983).

\section{RESULTS AND DISCUSSION}

1. Vegetative growth traits:

Data in Tables (2) reveal a gradual significant increase in all studied vegetative growth traits (i.e. plant height, number of leaves plant ${ }^{-1}$, total leaves area plant ${ }^{-1}$ and dry weights of leaves plant ${ }^{-1}$ ) was observed due to raising phosphate rates gradually applied from 100 up to $300 \mathrm{~kg} / \mathrm{fed}$, and also micronutrients applied from 0.1 up to $0.3 \%$, these results were true in both seasons. The greatest increases in growth parameters were obtained at the highest rate of micronutrients mixture $(0.3 \%)$. Such increases reached 7.39 and $8.14 \%$, for plant height; 11.77 and $12.57 \%$, for number of leaves/plant; 8.25 and $9.00 \%$, for total leaves area / plant and 12.18 and $12.96 \%$ for dry weight of leaves/ plant in the first and second seasons ,respectively, as compared to the control treatment. The corresponding increase percentages in growth parameters were also obtained by the highest rate of phosphate $(300 \mathrm{~kg} / \mathrm{fed})$ and reach increases reached 13.62 and $13.61 \%$, for plant height ; 26.63 and $26.75 \%$, for number of leaves/plant; 14.18 and $14.18 \%$, for total leaves area / plant and 14.10 and $14.03 \%$ for dry weight of leaves/ plant in the first and second seasons ,respectively ,as compared to the control plants. With respect to micronutrients and phosphate interaction effect, the data in Table (2) show that micronutrients at the rate of $0.3 \%$ plus phosphate at the rate of $300 \mathrm{~kg} / \mathrm{fed}$ gave the best results for all the studied plant parameters. The relative increase percentage 21.99 and $22.85 \%$, for plant height; 45.62 and $46.66 \%$, for number of leaves/plant; 22.71 and $23.55 \%$, for total leaves area/plant and 25.43 and $26.31 \%$ for dry weight of leaves/ plant in the first and second seasons, respectively, as compared to the control plants. The positive effect of phosphate on plant growth characteristics might be due to the fact that phosphorus element is an essential component of the energy compounds (ATP and ADP), genetic information system, cell membranes, phosphlipids,

Fayoum J. Agric. Res. \& Dev., Vol.23, No.2, July, 2009 
EFFECT OF PHOSPHATE AND SOME MICRONUTRIENT........ 98

phosphoproteins and nucleic acids. In general, these compounds are considered very important to plant growth (Gardener et al., 1985).

The positive effect of micronutrients on plant growth characteristics might be due to the fact that the essential role of $\mathrm{Zn}$ is related to the synthesis of tryptophan amino acid and consequently formation of auxin i.e. IAA which act as growth regulator especially in prolonging height of plants (Devendra, et al., (1999). Moreover, the increase in dry weight of leaves/plant could be attributed to its stimulating effect on vegetative growth and physiological processes, i.e. increasing number of cells through cell division and meristematic activity of tissues. Increasing number of leaves/plant (Table 2) due to the applied micronutrients may attributed to the obtained increment in dry weight of leaves. The stimulating effect of the used micronutrients on plant growth may be due to their role in transmission of the electron from water to chlorophyll and producing oxygen gas in the photosynthesis, in addition to their role in the nitrogen metabolism through activated nitrite reductase enzyme (Baza, 1984). Also, iron plays an important role in syntheses of ribonucleic acid, reduction of nitrate to ammonia (Russell, 1989) ,chlorophyll synthesis (Romheld and Maschnur, 1961), nucleic acid metabolism and catalytic and structural roles of $\mathrm{Fe}^{++}$and $\mathrm{Fe}^{+++}$in plant (Price et al., 1972 ). The most important function of manganese is related to the oxidation-reduction processes (Mengel and Krikby, 1982).

\section{Seed yield and their components:}

It could be stated from data of Table (3) that, foliar application of micronutrients at the concentrations of 0.1 up to $0.3 \%$ significantly increased seed yields and their components under study as compared to the control. Such results had a similar trend in both 2007 and 2008 seasons. The greatest increases in seed yield and their components were obtained at the highest rate of micronutrients mixture $(0.3 \%)$. Such increases reached 20.15 and $20.98 \%$ for head diameter, 15.59 and $17.83 \%$ for head dry weight 10.58 and $11.33 \%$ for seed weight plant $^{-1}, 8.73$ and $9.71 \%$ for 100 -seed weight and 10.76 and $11.53 \%$ for seed yield feddan ${ }^{-1}$ in 2007 and 2008 seasons, respectively. Also, the best results in seed yield and their components were obtained at the highest rate of phosphate $(300 \mathrm{Kg} / \mathrm{Fed})$, were the corresponding increases percentage, reached 37.96 and $37.95 \%$ for head diameter, 30.36 and $31.72 \%$ for head dry weight ,11.70 and $11.71 \%$ for seed weight plant $^{-1}, 12.20$ and $12.30 \%$ for 100 seed weight and 12.01 and $12.01 \%$ for seed yield feddan ${ }^{-1}$ in the first and second seasons, respectively. Moreover, Table (3) shows that, micronutrients at the rate of $0.3 \%$ plus phosphate at the rate $300 \mathrm{~kg} / \mathrm{fed}$ treatment gave the best results for all studied plant parameters. The relative increase percentage were 69.24 and $7047 \%$ for head diameter, 62.99 and $69.78 \%$ for head dry weight ,23.33 and $24.19 \%$ for seed weight plant ${ }^{-1}, 20.00$ and $20.85 \%$ for 100 seed weight and 24.14 and $25.01 \%$ for seed yield feddan ${ }^{-1}$ in the first and second seasons, respectively. Increasing effect of the used micronutrients on head diameter may be due to their simulative effect on cell division and expansion. Also the positive effect of there micronutrients on yield and its components was mainly attributed to their its role on enhancing growth parameters (Table2), i.e., photosynthetic pigments of plants leaves. Moreover, the increases in yield and its components may be attributed to the metabolic role of $\mathrm{Zn}, \mathrm{Fe}, \mathrm{Mn}$ and $\mathrm{P}$ in plant. The favorable effect of $\mathrm{Zn}, \mathrm{Fe}, \mathrm{Mn}$ and $\mathrm{P}$ on yield and its components might be attributed to the increases in photosynthetic

Fayoum J. Agric. Res. \& Dev., Vol.23, No.2, July, 2009 
Table 2

Fayoum J. Agric. Res. \& Dev., Vol.23, No.2, July, 2009 
Table 3

Fayoum J. Agric. Res. \& Dev., Vol.23, No.2, July, 2009 
pigment concentrations (Price $\boldsymbol{e t}$ al., 1972) as well as enzyme activity and consequently, enhancement of plant metabolism (Boardman, 1975). Also, zinc has an essential role in carbohydrates metabolism, protein synthesis, tryptophan and IAA synthesis, since it activates number of enzymes for photosynthesis (Gardner, et al., 1985 and Marschner, 1995).

\section{Chemical constituents:}

\section{a-Leaf macro and micronutrients:}

Data presented in Tables (4 and 5) show that the concentrations of studied macro and micronutrients in sunflower leaves (i.e. N, P, K, Fe, Mn and $\mathrm{Zn}$ ) significantly increased with increasing phosphate and micronutrients rates as comparison to the control. A similar trend was obtained in both the studied seasons. The applied micronutrients at the rate of $0.3 \%$ proved to be the best, where it and exhibits a pronounced increase in leaves content of $\mathrm{N}, \mathrm{P}, \mathrm{K}, \mathrm{Fe}$, $\mathrm{Mn}$, and $\mathrm{Zn}$. Such treatment surpassed the control by 4.28 and $4.85 \%$ for N, 10.52 and $10.00 \%$ for $\mathrm{P}, 12.50$ and $16.00 \%$ for $\mathrm{K}, 6.41$ and $6.96 \%$ for $\mathrm{Fe}$, 7.37 and $10.23 \%$ for $\mathrm{Mn}$ and 5.26 and $6.32 \%$ for $\mathrm{Zn}$ in the 2004 and 2005 seasons, respectively. Similar results were obtained with phosphate treatments at the rate $300 \mathrm{~kg} / \mathrm{fed}$. The best results were obtained with micronutrients at the rate of $0.3 \%$ plus phosphate at the rate $300 \mathrm{~kg} /$ fed for all the studied macro and micro nutrients. Increasing $\mathrm{N}, \mathrm{P}, \mathrm{K}, \mathrm{Fe}, \mathrm{Mn}$ and $\mathrm{Zn}$ concentrations in sunflower leaves in the present study may be attributed to the more availability and solubility of these elements to absorb by sunflower plants, where Papplication play an important role in lowering $\mathrm{P}^{\mathrm{H}}$ level needed for absorption of nutrients and consequently $\mathrm{N}, \mathrm{P}, \mathrm{K}, \mathrm{Fe}, \mathrm{Mn}$ and $\mathrm{Zn}$ concentrations were increased. Moreover, Devlin and Withman, (1985) reported that, the increase $\mathrm{N}, \mathrm{P}, \mathrm{K}, \mathrm{Zn}, \mathrm{Mn}$ and $\mathrm{Fe}$ in leaves may be due to the effect of $\mathrm{Zn}$ on biosynthesis of auxin (I.A.A.) which promote rooting process and consequently the amounts of mineral elements absorbed and translocated into the different parts of the plant. Also, El-Fouly and Fawzi, (1996) recorded that the use of micronutrients as foliar spraying led to an increase in root growth and their ability to higher uptake of micronutrients

\section{b- Chemical constituents of seeds:}

The data in Table (6) indicated that foliar application of micronutrients and soil application of phosphate at all the applied rates significantly increased seed contents of total carbohydrates, crude proteins and oils percentage (\%) . The best result were obtained by the use of micronutrients at the rate of $0.3 \%$ plus phosphate at the rate of $300 \mathrm{~kg} / \mathrm{fed}$.The relative increase percentages were 32.98 and $33.8 \%$ for total carbohydrates, 16.73 and $17.61 \%$ for crude proteins and 30.48 and $31.40 \%$ for oils percentage (\%)at the first and second seasons, respectively as compared to the control plants. The increase of total carbohydrates in the treated plants with micronutrients may be directly or indirectly due to that the certain enzymes may be activated the anabolic processes leading to the accumulation of these substances. In this concern, applied $\mathrm{P}$ resulted in an increase of total carbohydrates, this may be due to that $\mathrm{P}$ plays a fundamental role in large number of enzymatic reactions that dependents on phosphrylation. The increase of all mentioned constituents by foliar spray of micronutrients may be due to that certain enzymes may be activated as a result of these treatments leading to the accumulation of these substances. The increase of the above constituents by applying $\mathrm{P}$ may be

Fayoum J. Agric. Res. \& Dev., Vol.23, No.2, July, 2009 
EFFECT OF PHOSPHATE AND SOME MICRONUTRIENT....... 102

Table 4

Fayoum J. Agric. Res. \& Dev., Vol.23, No.2, July, 2009 
Table 5

Fayoum J. Agric. Res. \& Dev., Vol.23, No.2, July, 2009 
Table 6

Fayoum J. Agric. Res. \& Dev., Vol.23, No.2, July, 2009 
attributed to that $\mathrm{P}$ play an important role in enhancing metabolic process such as photosynthesis, starch synthesis and a constituents of high energy phosphate compounds.

In view of the obtained results, it could be concluded that application of micronutrients as a foliar spray solution at the concentration of $0.3 \%$ and phosphate $\left(\mathrm{P}_{2} \mathrm{O}_{5} 15.5 \%\right)$ at the rate of $300 \mathrm{~kg} /$ fed for sunflower (cv. Sakha 53) should be achieved high sufficient cellular solutes enable them to overcome carbonate of soils, particularly in the newly reclaimed soils, and consequently producing economic seed and oil yields under such soil conditions.

\section{REFERENCES}

A.O.A.C. (1995). Official Methods of Analysis of the Association of Official Agricultural Chemists. Sixteenth ed., Washington D.C., USA.

Baza, M.S. (1984): Effect of some macro and micro elements on growth and yields of maize. M.Sc. Thesis, Fac. Agric. at Moshtohr, Zagazig Univ., Egypt.

Boardman, N.K. (1975): Trace-elements in photosynthesis. In trace elements in Soil- Plant Animal System. Edited by Nicholas: 199-212 Academic Press. Inc., New York . San Francisco and London.

Chapman, H.D. and Pratt, P.F. (1961). "Methods of Analysis for Soil , Plants and Water. Univ. Calif., D.V., Agric. Sci., USA.

Devendra, T.; Najda, C.L. and Tak, D. (1999): Effect of growth regulators on growth and flower yield of tuberouse (Polianthes tuberosa L.) cv. single. Scientific Hort., 6: 147-150.

Devlin, R.M. and Withman, F.H. (1985). Plant Physiology. $4^{\text {th }}$ Ed. CBS Publishers and Distriibution, 485, Jain Bhawan, Bhola Nath Nagar, Shahdara. Delhi-110 032 (India), p. 443.

Dubois, M.F.; Gilles, K.A.; Hamiton, J.K.; Robers, P.A. and Smith, F. (1956). Colorimetric method for determination of sugars and related substances. Anal. Chem., 28: 350-354.

Elayan, Sohair, E.D. (2008): Effect of foliar application of some micronutrients on growth, yield and fiber properties on some Egyptian cotton cultivars. Egypt. J. of Appl. Sci., 23 (4B): 469-485.

El-Fouly, M.M. and Fawzi, A.F.A. (1996): Higher and better yield with less environmental pollution in Egypt through balanced fertilizer use. Fertilize Research, 43: 1-4.

El-Yazal, M.A (2007): Physiological studies on the effect of citrine on growth, yield and some chemical constituents of maize(Zea mays L.,) plants. Fayoum J. Agric. Res. \& Dev.,. 21 (2): 1-14

Fawzi, A.F.A. (1991): Micronutrients effect on filed crops in Egypt. Proc. $4^{\text {th }}$ Micronutrients Work Shop, Amman, Jordan, pp. 3-30.

Gardner, F.P.; Prearce, R.B. and Mitcheell, R.L. (1985). Physiology of Crop Plants. The Iowa State Univ. Press. Ames Iowa, U.S.A.

Gomez, K.A. and A.A. Gomez (1983). Statistical Procedure For Agricultural Research. A Wiley Inter-Science Publication, John Wiley \& Sons Inc., New York.

Hafez, A.R. and Mikkelsen, D.S. (1981). Colorimetric determination of nitrogen for evaluating the nutritional status of rice. Commun. Soil Sci. and Plant Anal., 12 (1): 61-69.

Herbert, D.; Phipps, P. J. and Strange, R. F. (1971). Determination of total carbohydrates. Methods in Microbian, 5 (B): 209-344.

Fayoum J. Agric. Res. \& Dev., Vol.23, No.2, July, 2009 
EFFECT OF PHOSPHATE AND SOME MICRONUTRIENT

Jackson, M.L. (1967). "Soil Chemical Analysis". New Delhi, Prentice Hall of India Private Limited, New Delhi, pp. 144-197 and 326-338.

Mabrouk, S.S. and Zayed, A. (2004): Varietal faba bean differences in nodulation, $\mathrm{N}$ content and yield under micronutrients foliar application. Agric. Res. J. Suez Canal University, 3: 159-166.

Marschner, H. (1995). Mineral Nutrition of Higher Plant. Second Edition. Academic Press Harcourt Brace and Company Publishing ,New York.

Mengel, K. and Kirkby, E.A. (1982). "Principles of Plant Narration", $3^{\text {rd }}$ Publisher. International Potash Institute, Worbalaufen- Bern /Switzerland, pp1, 593 and 655.

Page, A.I.; Miller, R.H. and Keeny, D.R. (1982). "Methods of Soil Analysis". Part II: Chemical and Microbiological Methods. $2^{\text {nd }}$ Ed. Amer. Soc. Agron., Madison, Wisconsin, USA.

Piper, C.S. (1947). "Soil and Plant Analysis". The University of Adelaide, Adelaide, UK.

Prabhurai, D.K. ;Badiger, M.K. andManure, G.R. (1995). Growth and yield of sunflower (helianthus annus, $\mathrm{L}$ ) as inflkuenced by levels of phosphorus, sulphur and zinc. Indian J. of Agronomy,38(3): 427-430.

Price, C.A.; Clark, H.E. and Funkhouser, E.A. (1972). Function of micronutrients in plants. Soil Sci., Society of America, 231.

Rahimizadeh, M.; Habibi, D.; Madani, H.; Mohammadi, G.N., Mehraban, A. and Sabet, A.M. (2007). The effect of micronutrients on antioxidant enzymes metabolism in sunflower (Helianthus annus L.) under drought stress Helia, 30 Nr. 47.p.p. 167-174.

Ranieri, A., Castagna, A. and Soldatini, G.F. (1999). Iron deficiency induces variations in oxidative stress bioindicators in sunflower plants. Agricoltura Mediterranea,129: 180-192.

Ranieri, A.; Castagna, A.; Baldan, B. and Soldatini, G. F. (2001). Iron deficiency differently affects peroxidase isoforms in sunflower. Journal of Experimental Botany, 52, (354): 25-35.

Rehan, M.G.; Seyam, H.M. and Abd- Allah, A.E. (2003): Broad bean (Vicia faba L.,) response to $\mathrm{P}$ and $\mathrm{Zn}$ interactions in calcareous soil. Egypt. J. Appl. Sci., 18: 706-714.

Romheld, W. And Maschnur, H. (1961). "USA Micronutrients in Agriculture, "2 ${ }^{\text {nd }}$ Ed. SSSA No. 4. Soil Sci., Society of America, $297 \mathrm{pp}$.

Russell, S.E.W. (1989). Soil Conditions and Plant Growth . $11^{\text {th }}$ Ed. Department of Soil Science, Univ. of Reading, Longman Group, UKLtd.

Seaf El-Yazal, S.A. (2004): The integrated effect of zinc and phosphate in combination with phosphorine as a biofertilizer on sunflower grown on the calcareous soils. Egypt.J. Appl. Sci.,19 (6B): 758-769.

Seaf El-Yazal, S.A. and El-Sayim, R.G. (2004): Acomparative study on faba bean response to iron, manganese and zinc as a soil or foliar application under Fayoum conditions. Egypt.J. Appl. Sci.,19 (6B): 743-757.

Soudi, Amal K.M. ,Omran, Samya, E. H. and Aboushady K.H. (2008): The response of sugar beet to mineral nitrogen and phosphorus fertilization, partial biofertilization and some micronutrients foliar application. Egypt. J. of Appl. Sci., 23 (4B): 502-516.

Fayoum J. Agric. Res. \& Dev., Vol.23, No.2, July, 2009 
تأثير التسميد الفوسفاتى وبعض المغذيات الصغرى على النمو والمحصول والمكونات الكيميائية لنباتات عباد الثمس النامية تحت ظروف المفى الأراضى المستصلحة حديثا

\section{قسم النبات الزراعي، كلية سيل الزراعةي، جامعة الفيوم.}

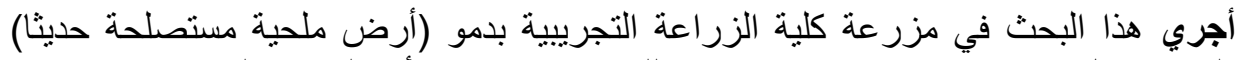

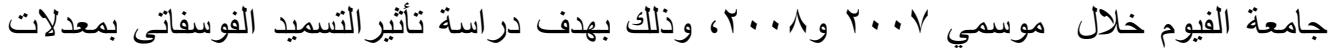

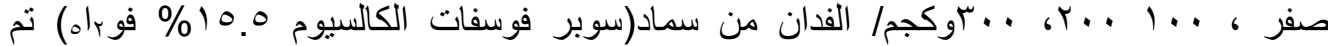

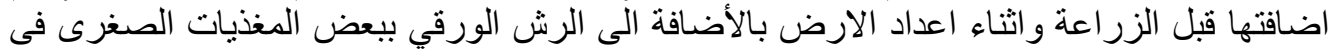

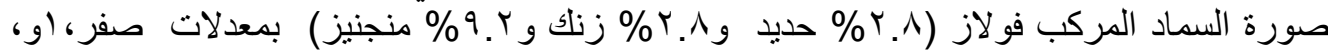

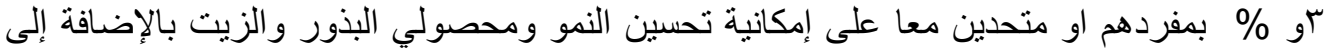

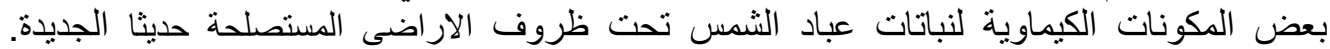

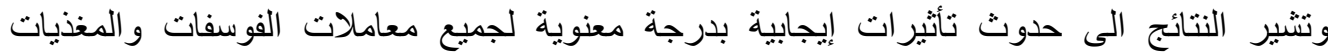

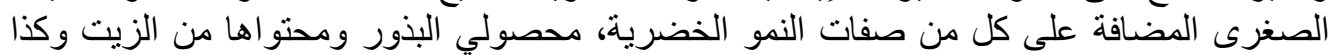

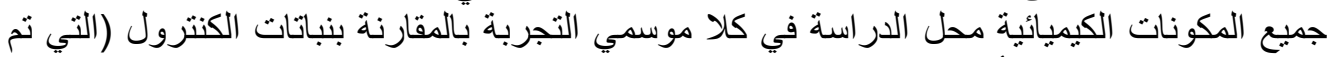

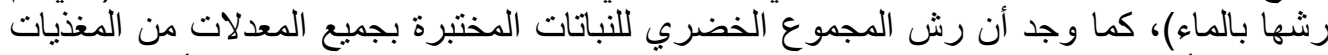

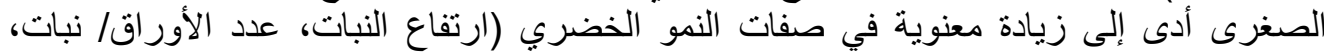

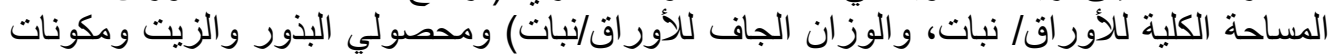

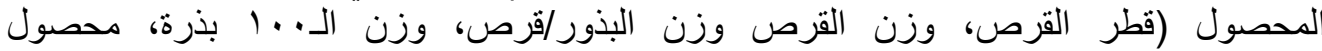

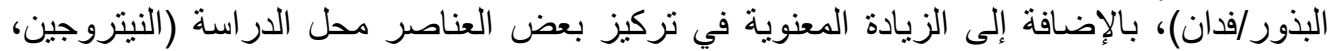

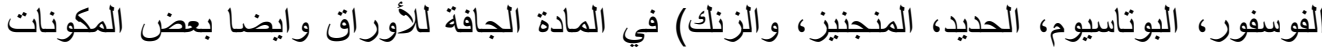

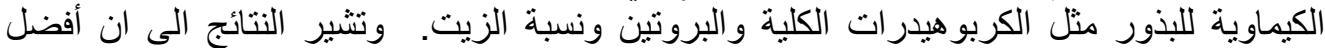

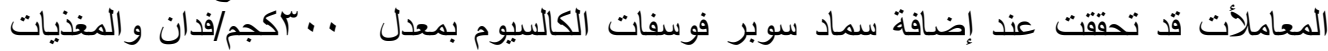

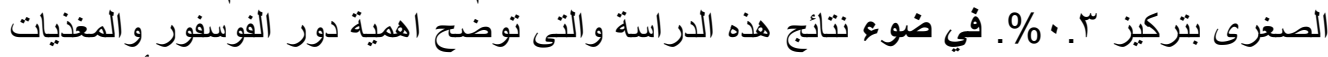

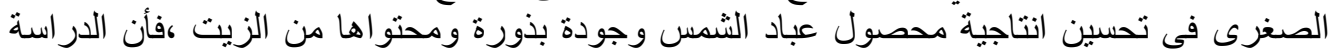

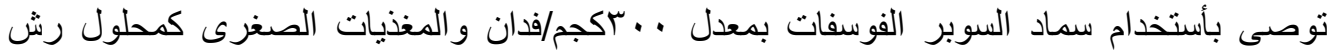

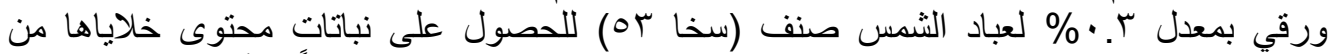

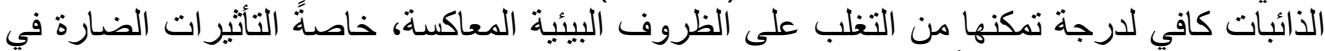

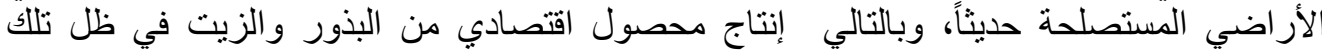
الظروف المذكورة.

Fayoum J. Agric. Res. \& Dev., Vol.23, No.2, July, 2009 